\title{
Autogenous Deformation of Alkali-Activated Blast Furnace Slag Concrete Subjected to Variable Curing Temperatures
}

\author{
Katalin Orosz, ${ }^{1}$ Abeer Humad, ${ }^{1}$ Hans Hedlund, ${ }^{2}$ and Andrzej Cwirzen ${ }^{1}{ }^{1}$ \\ ${ }^{1}$ Department of Civil, Environmental and Natural Resources Engineering, Luleå University of Technology, \\ SE-971 87 Luleå, Sweden \\ ${ }^{2}$ Skanska Sverige AB, SE-405 18 Gothenburg, Sweden \\ Correspondence should be addressed to Andrzej Cwirzen; andrzej.cwirzen@ltu.se
}

Received 30 October 2018; Revised 21 January 2019; Accepted 5 February 2019; Published 28 April 2019

Academic Editor: José Aguiar

Copyright (c) 2019 Katalin Orosz et al. This is an open access article distributed under the Creative Commons Attribution License, which permits unrestricted use, distribution, and reproduction in any medium, provided the original work is properly cited.

Deformations of alkali-activated slag concrete (AASC) with high $\mathrm{MgO}$ and $\mathrm{Al}_{2} \mathrm{O}_{3}$ content, subjected to variable curing temperature were studied. Sodium silicate and sodium carbonate were used as alkali activators. The obtained results showed development of deformations consisting of both shrinkage and expansion. Shrinkage appeared not to be affected by the activator type, while the expansion developed after the cooling down phase in stabilized isothermal conditions and did not stop within the duration of the tests. X-ray diffraction analysis performed shortly after the cooling down phase indicated the formation of crystalline hydrotalcite, which was associated with the observed expansion. A mixture with a higher amount of sodium silicate showed less expansion, likely due to the accelerated hydration and geopolymerization leading to the increased stiffness of the binder matrix.

\section{Introduction}

The development of alkali-activated materials (AAMs) has been in the focus of interest over the last few decades [1-5]. Alkali-activated slag (AAS) and AASC (alkali-activated slag concrete) are made by activating granulated blast furnace slag (GGBS) with alkali solutions. The Portland cement can be replaced entirely, thus offering a substantially reduced environmental impact over conventional concrete. Concretes made with GGBS are less sensitive to early-age thermal cracking due to generated heat of hydration [6]. The hardened concrete has a denser microstructure with smaller and fewer capillary pores, resulting in enhanced ability to withstand chemical attacks [7]. The strength of AAS concretes is comparable to ordinary Portland cement (OPC) concrete; compressive strengths as high as 100$130 \mathrm{MPa}$ have been reported $[8,9]$. GGBS is mostly an amorphous, glassy material containing mainly calcium and aluminosilicates. In a high calcium system, alkali activation renders the aluminosilicates into a reactive form. In the presence of water and alkalis, AAS produce primarily calcium silicate hydrates (C-S-H), similar to that observed in OPC, but with a lower $\mathrm{Ca} / \mathrm{Si}$ ratio and a higher $\mathrm{Al}$ content $[10,11]$ and calcium-aluminosilicate hydrates $(\mathrm{C}-\mathrm{A}-\mathrm{S}-\mathrm{H})$. Since the gel contains a certain amount of sodium $(\mathrm{Na})$, it is often referred to as $(\mathrm{C}-(\mathrm{N})-\mathrm{A}-\mathrm{S}-\mathrm{H})$. The $\mathrm{C}-\mathrm{A}-\mathrm{S}-\mathrm{H}$ gel exhibits nanocrystallinity, while the $\mathrm{C}-(\mathrm{N})-\mathrm{A}-\mathrm{S}-\mathrm{H}$ type gel is amorphous [12]. The exact type of gel that forms depends on the calcium and magnesium content of the system, the type and $\mathrm{pH}$ of the activator, and the curing conditions[13 -17]. The mechanisms of hydration in AAS have been shown to be different $[10,18]$.

Widespread industrial adoption of AAS has been hindered by the lack of data on long-term performance and durability. Furthermore, driving mechanisms of autogenous shrinkage are not fully understood. Shrinkage is considered as an important engineering property due to the risk of cracking when deformations in the material are internally restrained by aggregates.

For cement-based materials, the autogenous shrinkage is closely related to the chemical shrinkage, microstructure development and the internal relative humidity of the 
material, [19-22]. The drying shrinkage of concrete is mainly influenced by the paste volume, the surface area exposed to drying, the relative humidity of the surroundings [23], and the rate of capillary pressure development [24]. In alkaliactivated materials, both the autogenous and the drying shrinkage behaviour appear to be more complex than in OPC. Both autogenous and drying shrinkage in AAS have shown to exceed that of a comparable strength OPC $[9,25,26]$. It has been found that chemical, autogenous and drying shrinkage increase with the addition of more slag and sodium silicate [27]. Drying shrinkage lower than that in OPC mortar was obtained in AAS when using sodium carbonate as activator, instead of sodium silicate [28]. Different activators generate coarser or finer capillary porosity [29], which is expected to influence the shrinkage behaviour. Porosity is also affected by the amount of slag in the mix; an increase in slag content results in reduced total porosity and a denser microstructure [27]. Higher Blaine fineness of slag resulted in greater reactivity and higher porosity [30]. Heat curing, besides providing high early strength, reduced drying shrinkage in AAS [31]. No clear relationship between drying shrinkage and moisture loss in AAS has been established. Despite the higher drying shrinkage observed in AAS, the actual moisture loss in AAS was less than in the comparable OPC samples [25]. The authors attributed the greater drying shrinkage observed in AAS to the increased amount of smaller pores having radius corresponding to mesorange $(5-50 \mathrm{~nm})$, which increased the capillary stresses developed during their emptying $[25,26,32,33]$. In contrast, consistently higher moisture loss compared to OPC was also observed in AAS [34]. The authors reported on irregular drying shrinkage behaviour where lower ambient humidity (faster rate of drying) did not necessarily translate into more rapid shrinkage development, indicating that (drying) shrinkage mechanisms in AAS are significantly more complex than in OPC.

Research focusing specifically on autogenous shrinkage in alkali-activated materials is limited. Alkali activation of slag by a sodium silicate solution may result in twice the chemical shrinkage of a comparable OPC paste [35]. Autogenous shrinkage of AAS mortars was tested by the corrugated tube method [9] under isothermal conditions and linear autogenous shrinkage strains reaching 2700-2800 $\mu \varepsilon$ over ca. 8 months have been recorded for AASC mixes activated with both plain sodium hydroxide $(\mathrm{NaOH})$ pellets or a combination of sodium hydroxide and aqueous sodium silicate or waterglass $\left[\mathrm{Na}_{2} \mathrm{O}\left(\mathrm{SiO}_{2}\right)_{n}\right]$, while about $400 \mu \varepsilon$ shrinkage strain was obtained in the OPC reference mix. The development of autogenous shrinkage did not slow down significantly over the observed period of 8 months while the OPC reference stabilized around the 3-month mark. The driving mechanism behind the autogenous shrinkage in AAS is not clarified. On one hand, the chemical shrinkage is greater than that in OPC, while the AAS C-S-H has been found to have lower atomic packing density than the $\mathrm{C}-\mathrm{S}-\mathrm{H}$ in OPC; "thus, the large chemical shrinkage associated with AAS hydration is likely related to the glassy nature of the slag itself, which results in a relatively low atomic packing density of the unhydrated material" [35]. Others concluded that the main driving mechanism behind the autogenous shrinkage of alkali-activated fly ash/slag (AFS) was the accelerated selfdesiccation due to the decreasing internal relative humidity in the mesopores in the hardened state rather than chemical shrinkage in the fresh state [27]. In the same study, it was also found that the mesopores made up $60-80 \%$ of the total pore volume vs. $36 \%$ in OPC paste. Another study states that up to $90-95 \%$ of the total pore volume is mesopores in AAS [26]. One study reported on shrinkage measurements in AAM samples kept at $99 \% \mathrm{RH}$ (which can be considered autogenous conditions) where the introduction of polypropylenglycol-based shrinkage-reducing admixtures (SRA) in waterglass-activated slag mortars resulted in shrinkage reduction through induced expansion [36]. Addition of $1 \%$ SRA resulted in a $\sim 200 \mu \varepsilon$ expansion over a period of 25 days (Figure 1). Increasing the amount of SRA to $2 \%$ led to a lesser expansion. The authors also observed expansion in the OPC reference and a minimal, but clearly detectable expansion in the AAS without SRA. There is no clear agreement whether the autogenous or the drying shrinkage is the dominant mechanism causing volumetric changes in AAS [37].

For practical applications, it is important that the materials are tested under realistic curing conditions. Most alkali-activated materials benefit from heat-curing and hence are habitually heat-cured in order to gain early compressive strength faster, and for fly ash geopolymers heat curing is required [38]. However, shrinkage tests are typically performed under ambient temperature conditions or past heat-curing - by when most of the shrinkage has already developed.

This paper presents experimental results of the autogenous deformation behaviour of AAS undergoing variable temperature ("realistic") curing.

\section{Experimental Program}

2.1. Materials. For the AASC mixes, ground granulated blast furnace slag (GGBS, Merit 5000) provided by MEROX, Sweden was used in this study. Its chemical composition, determined by XRF spectrometry, along with the known properties of the cement used for the ordinary Portland cement concrete mixes are listed in Table 1. The mix designs are summarized in Table 2. No superplasticizers were used in any of the studied AASC mixes. All mixes contained $450 \mathrm{~kg} /$ $\mathrm{m}^{3}$ of GGBS and had the $\mathrm{w} / \mathrm{b}$ ratio of 0.45 . The only difference in the mixes is the type and the amount of the used alkali activator (10 wt.\% and $14 \mathrm{wt} . \%$ of the binder weight). Sodium silicate (SS) and sodium carbonate (SC) and their combination were used. The sodium carbonate was provided in dry powder form by CEICH S.A. The aqueous solution of sodium silicate (SS) was provided by PQ Corporation. SS had alkali modulus $\left(\mathrm{SiO}_{2} / \mathrm{Na}_{2} \mathrm{O}\right)=2.2$ with 34.37 wt. $\% \mathrm{SiO}_{2}$, 15.6 wt.\% of $\mathrm{Na}_{2} \mathrm{O}$ and a solid content of $49.97 \mathrm{wt} . \%$. The alkali modulus of the liquid SS was adjusted to 1.00 by adding chemically $98 \%$ pure sodium hydroxide $(\mathrm{NaOH})$ pellets. The activator solution was prepared 24 hours prior to mixing. After mixing all dry ingredients for 3 minutes in a Hobart mixer, the activator was added and mixing 


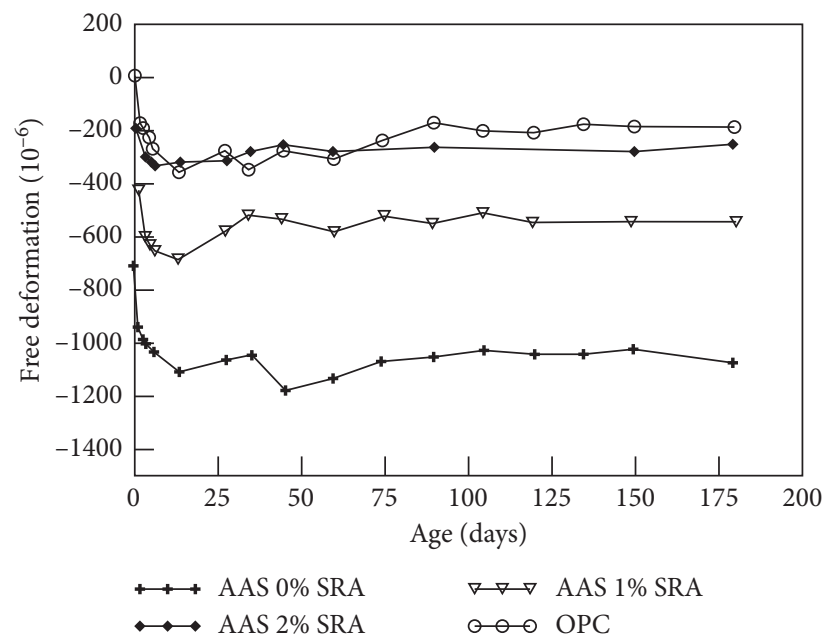

FIgURE 1: Deformation in waterglass-activated slag mortars with SRA (data from [36]).

TABle 1: Physical and chemical properties of binders.

\begin{tabular}{|c|c|c|c|c|c|c|c|c|c|c|}
\hline $\begin{array}{l}\text { Slag } \\
\text { Oxides (wt.\%) }\end{array}$ & $\begin{array}{l}\mathrm{CaO} \\
30.4\end{array}$ & $\begin{array}{l}\mathrm{SiO}_{2} \\
34.97\end{array}$ & $\begin{array}{c}\mathrm{Al}_{2} \mathrm{O}_{3} \\
14.34\end{array}$ & $\begin{array}{c}\mathrm{Fe}_{2} \mathrm{O}_{3} \\
0.34\end{array}$ & $\begin{array}{l}\mathrm{MgO} \\
16.14\end{array}$ & $\begin{array}{c}\mathrm{Na}_{2} \mathrm{O} \\
0.59\end{array}$ & $\begin{array}{l}\mathrm{K}_{2} \mathrm{O} \\
0.69\end{array}$ & $\begin{array}{l}\mathrm{TiO}_{2} \\
2.82\end{array}$ & $\begin{array}{c}\mathrm{MnO} \\
0.50\end{array}$ & $\begin{array}{l}\mathrm{SO}_{3} \\
0.65\end{array}$ \\
\hline \multirow[t]{2}{*}{ Physical data } & \multicolumn{2}{|c|}{$\begin{array}{l}\text { Specific surface } \\
\qquad\left(\mathrm{kg} / \mathrm{m}^{2}\right)\end{array}$} & \multicolumn{2}{|c|}{$\begin{array}{l}\text { Particle density } \\
\left(\mathrm{kg} / \mathrm{m}^{3}\right)\end{array}$} & \multicolumn{2}{|c|}{$\begin{array}{l}\text { Bulk density } \\
\left(\mathrm{kg} / \mathrm{m}^{3}\right)\end{array}$} & \multicolumn{2}{|c|}{$\begin{array}{c}\text { Moisture } \\
\text { content (\%) }\end{array}$} & \multicolumn{2}{|c|}{$\begin{array}{c}\text { Glass content } \\
(\%)\end{array}$} \\
\hline & \multicolumn{2}{|c|}{450} & \multicolumn{2}{|c|}{3000} & \multicolumn{2}{|c|}{$<2 \mathrm{ppm}$} & \multicolumn{2}{|c|}{ - } & \multicolumn{2}{|c|}{-} \\
\hline
\end{tabular}

TABle 2: Mix proportions and mix properties.

\begin{tabular}{lccc}
\hline Amount $\left(\mathrm{kg} / \mathrm{m}^{3}\right) / \mathrm{mix}$ & $\mathrm{SC} 10$ & $\mathrm{SS} 10$ & $\mathrm{SS} 14$ \\
\hline Slag & 450 & 450 & 450 \\
$0 / 4$ & 1332 & 1332 & 1332 \\
$4 / 8$ & 331 & 331 & 331 \\
Water, eff. & 202.5 & 202.5 & 202.5 \\
Cement & - & - & - \\
Activator & $10 \% \mathrm{SC}$ & $10 \% \mathrm{SS}$ & $14 \% \mathrm{SS}$ \\
Alkali modulus & - & 1.00 & 1.00 \\
pH of activator & 11.2 & 13.7 & 13.7 \\
28-day cube strength $(\mathrm{MPa})$ & 48 & 50 & 77 \\
\hline
\end{tabular}

continued for additional 4 minutes. The 28-day compressive strength was determined on $100 \times 100 \times 100 \mathrm{~mm}$ cubes. Immediately after casting, all samples were sealed in plastic bags.

2.2. Test Methods. Fully coupled autogenous and thermal deformations were recorded on $\varnothing=80 \mathrm{~mm}, h=300 \mathrm{~mm}$ concrete cylinders by means of two symmetrically mounted Schaevitz type $010 \mathrm{MRH}$ linear variable deformation transducers. The gauge length was $100 \mathrm{~mm}$. The results represent the average of the two linear variable differential transformers (LVDTs) readings per sample. The scatter across the measurements per material was less than $10 \%$. To facilitate demoulding the AASC samples at 8 hours, the cylinder moulds were lined with transparent plastic foil before casting. The demolded cylindrical samples, with the mounted LVDTs, were placed inside a waterproof casting which was then submerged in water. The curing temperature was regulated with $\pm 3^{\circ} \mathrm{C}$ accuracy by changing the water temperature. Initially, the imposed temperature path followed the adiabatic temperature development for the concrete based on OPC and with a W/B ratio of 0.38 [39]. After reaching the prescribed curing temperature, the steering consisted of a constant temperature curing, a steady-rate cooling down stage, and steady room temperature curing (Figure 2). The total duration of the tests was 14 days. The recorded data consisted of the free deformation, the temperature in the centre of the sample measured by a cast in thermocouple, the temperature of the water bath, and the ambient temperature. LVDTs were mounted on the already hardened samples. Here, the samples were demolded at 8 hours of age and the deformations zeroed at 8.5 hours (after mounting the LVDTs). Prior to the tests, the test setup and logging equipment were validated by recording the thermal deformations on a steel pipe. The recorded deformations closely follow the temperature steering, consisting of straight lines, with a minimal deviation (Figure 2). The curing temperature path and the recorded temperature development in the centre of the heat-cured samples are shown vs. the real time measured after casting. Positive values indicate expansion while negative contraction (shrinkage). Lab room temperature $\left(20^{\circ} \mathrm{C}\right)$ isothermal reference samples are also plotted, with the exception of the SS14 sample where no data are available.

The XRD analysis was done on 28-day-old powdered paste samples using a PAN analytical Empyrean XRD unit operating with $\mathrm{Cu} \mathrm{K} \alpha$ radiation. The total scanning time for each sample was 15 minutes and the step size was $0.0262^{\circ} 2 \theta$. The samples were heat-cured following the procedure 


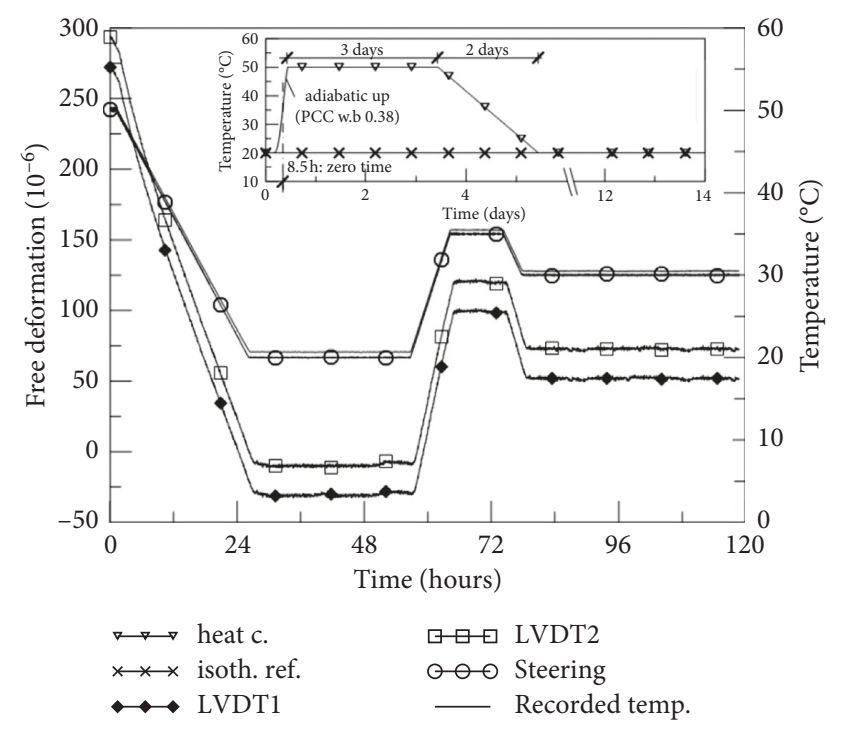

FIGURE 2: Deformation recorded on steel pipe (nonzeroed).

applied to the free deformation cylinders. All samples were crushed and grinded after 168 hours. The XRD analysis was performed within two hours after powdering of the samples, which excluded the need to use solvents to stop the hydration.

\section{Test Results and Discussion}

Application of heat curing requires decoupling of autogenous and thermal deformations to enable separate quantifications of both mechanisms. For successful decoupling, it is crucial to use the correct thermal coefficient, in particular for early-age materials when it is expected to be highly nonlinear. However, in the current study, no decoupling has been attempted. Due to the different hydration/ geopolymerization processes in AAM, the thermal coefficients taken from the literature for concrete would not be applicable. At the moment of writing, no data on the development of the thermal coefficient specific to early-age AAM exist.

Recorded free deformations of concrete samples are presented in Figures 3-6. The total deformations of isothermally cured reference AASC samples exceeded significantly values observed earlier for OPC [40]. The SS10 reference shrank about twice as much as the SC10. Similar trends were observed earlier, Duran Atics et al. [28]. The SC10 mix developed virtually no shrinkage $(<20 \mu \varepsilon)$ for the first 32 hours of the heat curing at high temperature (Figure 5). Since there is no singularity in the heat curing that could have caused the sharp change in the rate of shrinkage at around 40 hours, the shape of the curve suggest that expansive products might have formed already at that early stage. There was no such slope change observed in the SS10 reference sample. It is important to underline that deformations during the first 8.5 hours were not recorded due to the used experimental setup. Consequently, it is unknown how the 14-day shrinkage would have developed if the measurements would start right after casting. For example,

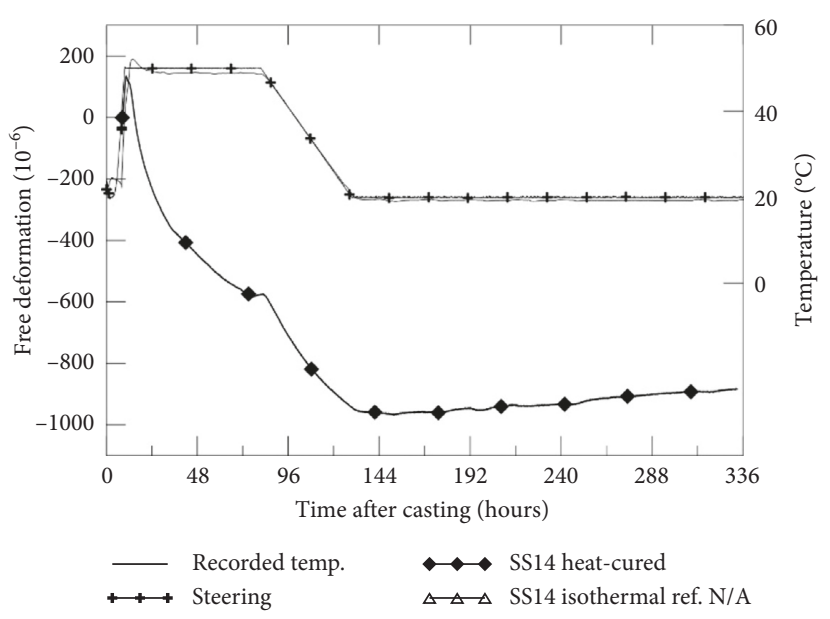

Figure 3: Free deformations and temperature development recorded on SS14 heat-cured sample.

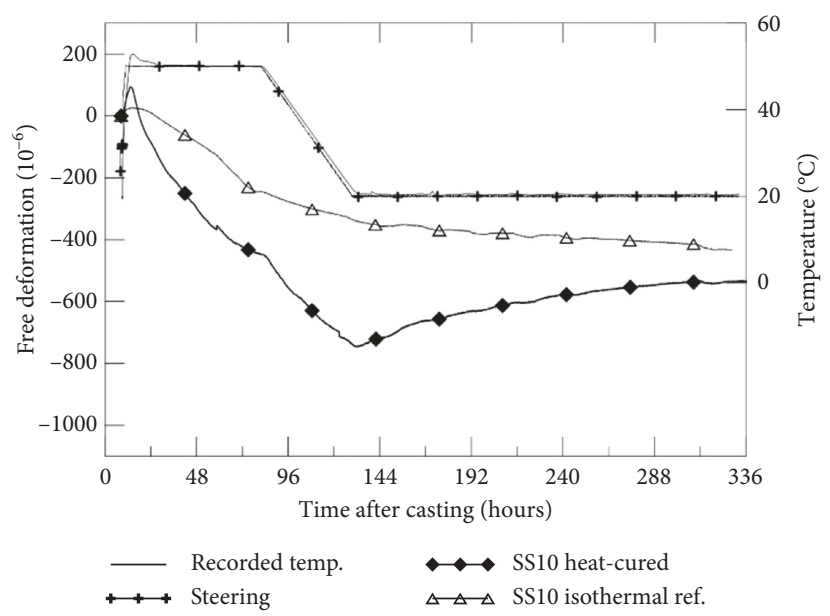

FIgURE 4: Free deformations and temperature development recorded on SS10 samples.

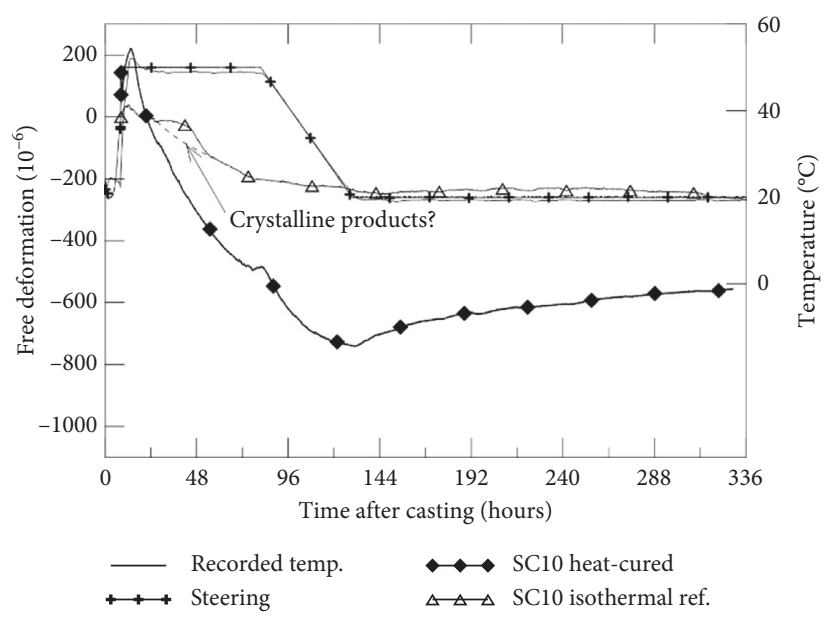

FIgURE 5: Free deformations and temperature development recorded on SC10 samples.

the difference between sodium silicate and carbonate could be even more significant. These results correlate with earlier tests on AAS activated with a mix of sodium silicate and 


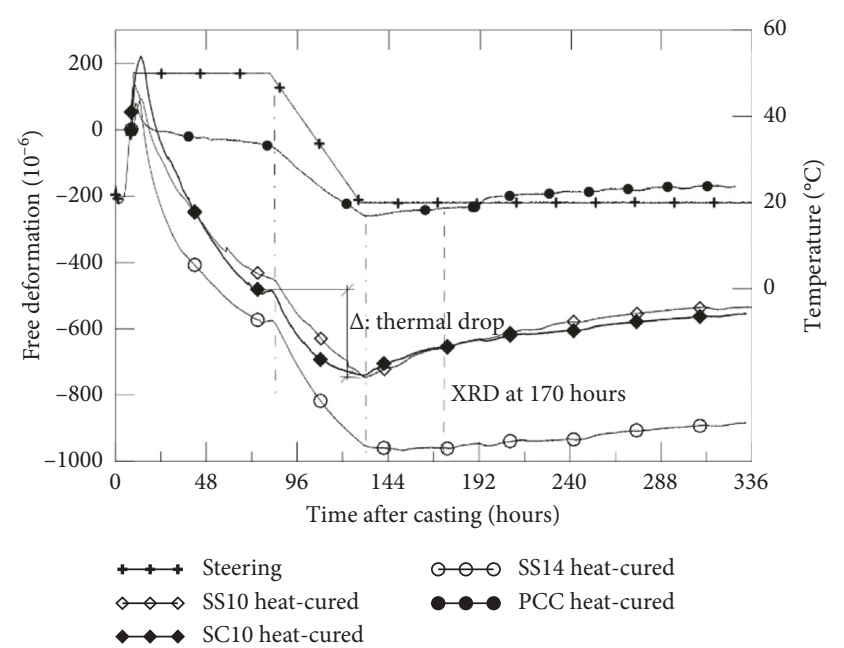

FIGURE 6: Free deformations on heat-cured samples, comparison.

sodium hydroxide where autogenous shrinkage strains up to 7 times larger than in OPC were obtained [18].

The influence of the activator type, sodium silicate vs sodium carbonate on the magnitude, and development rate of the shrinkage was minimal for the heat-cured samples (Figure 6). Increasing the amount of the sodium silicate activator from 10 to $15 \mathrm{wt}$.\% resulted in a initially higher rate of shrinkage development, which complied with earlier studies [26]. However, about 48 hours after casting, the shrinkage rates of the SS10 and SS14 were nearly identical. After 130 hours, the expansion in SS14 was noticeably slower than that in the other two samples with lower amounts of activator; the rate at which the SC14 sample swelled.

Autogenous expansion was observed in all heat-cured samples. The expansion was clearly identifiable after the 130hour mark where the curing temperature was kept constant. However, based on the slope change during the cooling down stage, it is likely that the expansion begun already while the samples were cooling down. Such expansion, beginning during cooling down, is not uncommon to OPC $[41,42]$. The sodium carbonate sample started to swell earlier during the cooling down stage than the sodium silicate sample, as indicated by the slope of the free deformation curves shifting upward during the cooling down period. The differences in deformation behaviour due to increasing the amount of activator could partly be explained by the differences in the developing pore structure. For example, larger observed amounts of smaller mesopores (diameter 5-50 nm) forming in alkali-activated binders were related to the development of higher capillary stresses during their emptying $[25,26,32,33]$.

The thermal drop marked with $\Delta$ in Figure 6 and listed in Table 3 indicates coupled autogenous and thermal deformation $(\mathrm{AD}+\mathrm{TD})$ during the cooling down stage. $\mathrm{TD}$ is calculated as $\alpha * \Delta \mathrm{T}$, where $\alpha$ is the thermal dilation coefficient and $\Delta \mathrm{T}$ is the temperature change. The value of $\alpha$ in cement-based materials is closely connected to the internal $\mathrm{RH}$ of the sample [43] and may be also influenced by the pore structure in the concrete body [44]. Unfortunately, the development of the thermal coefficient in AAM is not well studied. However, the observed variations in thermal drop indicated differences in material properties at that curing stage, i.e., different moisture content, hydration products, and/or pore structure. The contraction for the SS14 sample during cooling down was about 30\% larger than in the S10 sample (Table 3 ). The contraction $\Delta$ was partly autogenous and thermal, related to the coefficient of thermal expansion, CTE. In ordinary concrete, the CTE decreases sharply right after casting due to large amounts of free water (above $\left.20 \times 10^{-6} /{ }^{\circ} \mathrm{C}\right)$ to a minimum value around setting time $\left(\sim 7 \times 10^{-6} /{ }^{\circ} \mathrm{C}\right)$ [45-47]. Thereafter, it slowly increases due to self-desiccation, converging to the value characteristic for the hardened concrete $\left(9 \ldots 12 \times 10^{-6} /{ }^{\circ} \mathrm{C}\right)$ [43]. The reduction around setting time is due to the fact that while still plastic, the free water is continuous, while during the formation of the solid skeleton, this continuity gets disrupted. Considering that, the hydration rate of the SS14 is faster, and the thermal coefficient is skewed by the water content. Consequently, it should be lower in a material with the accelerated hydration rate. It can be deduced that, in the AAS, the developing pore structure or the different proportions of hydration/ geopolymerization products, or other yet unknown factors have a significant impact on the CTE [44].

The differences in density, porosity, and $\mathrm{Ca} / \mathrm{Si}$ ratio in the $\mathrm{C}-\mathrm{S}-\mathrm{H}$ forming in AAS vs OPC and the larger paste volume together account for the much larger deformations (contractions) observed in the AAS [10,35]. The slag used in the present study slag had a high $\mathrm{MgO}$ (15.81 wt.\%) and moderate $\mathrm{CaO}$ (29.78 wt.\%) content (Table 1). AAM systems with high calcium and magnesium content tended to form C-(A)-S-H dominated gels which are less porous than the polymerized gel that forms in a system with a low $\mathrm{Ca}[16,48]$. In the present study, the dominant phases in AAS were identified as $\mathrm{C}-(\mathrm{A})-\mathrm{S}-\mathrm{H}$ gel and calcite $\left(\mathrm{CaCO}_{3}\right)$, which complies with earlier results [49] (Figure 7). High $\mathrm{Al}_{2} \mathrm{O}_{3}$ content of slag has been related to the formation of larger amounts of ettringite, [10]. The slag used here had a high, 23.5\% $\mathrm{Al}_{2} \mathrm{O}_{3}$ content $\left(\mathrm{Al}_{2} \mathrm{O}_{3} /\left(\mathrm{CaO}+\mathrm{Al}_{2} \mathrm{O}_{3}+\mathrm{MgO}\right)\right)$. However, neither ettringite $\left(\mathrm{Ca}_{6} \mathrm{Al}_{2}\left(\mathrm{SO}_{4}\right)_{3}(\mathrm{OH})_{12} \cdot 26 \mathrm{H}_{2} \mathrm{O}\right)$ nor hydrogarnets were detected in either AAS mix, contrary to earlier findings $[10,50]$. In addition, brucide peaks were not detected despite the overall trend for their formation in cementitious systems rich in $\mathrm{MgO}$ [51]. It is possible that such formation actually occurred, but earlier in the hydration process converting later into hydrocalcite [51, 52]. Calcite peaks were detected only in the AAS mix activated with sodium carbonate. The use of sodium carbonate as activator has been associated with a prolonged hardening process [49], in which the alkalinity required to fully dissolve the slag develops slowly. Prior to the formation of C(A) $-\mathrm{S}-\mathrm{H}, \mathrm{Ca}^{2+}$ ions from the dissolved slag react with $\mathrm{CO}_{3}{ }^{2-}$ from the activator to form calcite $\left(\mathrm{CaCO}_{3}\right)$, which in turn will raise the alkalinity. The presence of calcite as a minor or trace reaction product in AAS activated with sodium carbonate was also confirmed by Myers [53]. A typical hydration product in AAS is hydrotalcite $\left(\mathrm{Mg}_{6} \mathrm{Al}_{2}\left(\mathrm{CO}_{3}\right)(\mathrm{OH})\right.$ $16 \cdot 4\left(\mathrm{H}_{2} \mathrm{O}\right)$ - a magnesium aluminate hydrate). Its formation depends on the $\mathrm{MgO}$ content of the slag, activator type, and curing conditions, e.g., $[11,29,49,50,52-54]$. It usually 
TABLE 3: Comparative deformation values.

\begin{tabular}{lcccc}
\hline Sample & $\begin{array}{c}\Delta \text { thermal drop } \\
(\mu \varepsilon)\end{array}$ & $\begin{array}{c}\text { Early expansion due to heat of hydration } \\
(\mu \varepsilon)\end{array}$ & $\begin{array}{c}\text { Shrinkage before cooling down } \\
(\mu \varepsilon)\end{array}$ & $\begin{array}{c}\text { Expansion past 130 hours } \\
(\mu \varepsilon)\end{array}$ \\
\hline SS10 & 290 & 90 & -540 & 210 \\
SC10 & 250 & 225 & -730 & 190 \\
SS14 & 380 & 150 & -710 & 65 \\
\hline
\end{tabular}

precipitates in the form of tiny crystals forming within the $\mathrm{C}-\mathrm{S}-\mathrm{H}$ [55]. Higher $\mathrm{MgO}$ contents have been linked to a denser microstructure and higher compressive strength because of additional hydrotalcite forming [11]. The available $\mathrm{Al}_{2} \mathrm{O}_{3}$ first tends to form hydrotalcite (and hydrogarnets/ettringite), followed by the formation of $\mathrm{C}-$ (A) $-\mathrm{S}-\mathrm{H}$ and AFm, depending on the $\mathrm{Ca} / \mathrm{Si}$ ratio $[50,56]$. Small but detectable hydrotalcite peaks have been identified for all three heat-cured AAS mixes at 11.3, $46.0 \mathrm{deg}$. The remaining three characteristic for hydrotalcite peaks at 22.7, 34.6 , and 38.9 were overshadowed by other present crystalline phases. Hydrotalcite forms small platelets, which is one possible reason for the observed expansion. Less extensive expansion observed in the mix SS14 could be related to the accelerated hydration and thus increased strength development rate. Consequently, at the stage when expansion due to hydrotalcite formation occurs, a stiffer skeleton was built which resists deformations better.

It is important that shrinkage tests are performed under realistic curing conditions corresponding to a real structure. Application of heat curing can result in significant differences between the deformation behaviour of concrete cured at ambient temperature vs. a heat-cured [42]. If heat curing is involved, decoupling of autogenous and thermal deformations is necessary in order to be able to quantify both mechanisms separately. For successful decoupling, it is crucial to use the correct thermal coefficient, in particular at an early age when it is expected to be nonlinear. In the current study, no decoupling has been attempted due to lack of reliable data related to the development of the thermal coefficient specific to early-age AAM.

\section{Conclusions}

Autogenous deformations of alkali-activated concretes based on high $\mathrm{MgO}$ content BFS subjected to variable curing temperatures were determined. The applied curing procedure aimed to simulate realistic temperature development. In general, the observed ultimate shrinkage values were higher in comparison with results published previously for concretes based on Portland cement. It was concluded that a combination of hydration and geopolymerisation processes, which occur in alkali-activated slag systems, produced microstructure containing larger amount of smaller pores. This could lead to higher tensile stresses and thus to the increased shrinkage.

The recorded ultimate maximum deformation was not affected by the used type of alkali activator for the heat-cured samples sodium silicate vs sodium carbonate. However, an increased amount of sodium silicate from 10 to $14 \mathrm{wt} . \%$ resulted in significantly larger deformation.

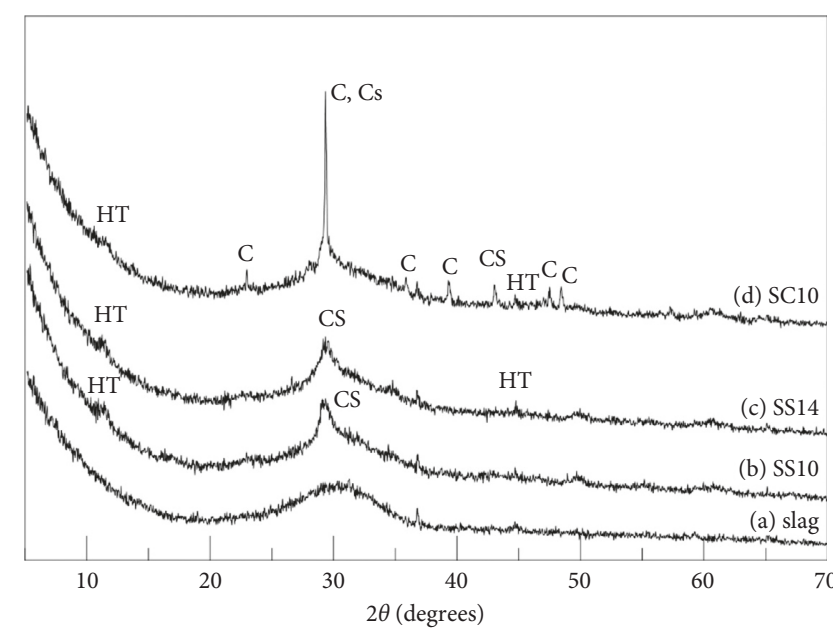

HT hydrotalcite

C calcite

CS CASH (CSH)

FIGURE 7: X-ray diffractograms at one week of age: (a) unreacted slag, (b) heat-cured SS10, (c) heat-cured SS14, and (d) heat-cured SC10.

Autogenous expansion has been detected in all AASC mixes. It was not possible to determine the exact onset of the expansion without decoupling the autogenous and thermal deformations; however, based on slope changes in the free deformation plots, the expansion presumably begun during the cooling down stage. The expansion did not level off during the duration of the tests. The observed expansion was associated with formation of hydrotalcite due to a high $\mathrm{MgO}$ content of the used BFS.

\section{Data Availability}

The data used in this study will be provided upon request.

\section{Conflicts of Interest}

The authors declare that they have no conflicts of interest.

\section{Acknowledgments}

The data used in the publication originate from $\mathrm{Ph}$.D. thesis published at Lulea University of Technology [39]. The funding for this OPC part of this project was provided by Trafikverket (Swedish Road Administration) and SBUF (Development Fund of the Swedish Construction Industry). The materials were supplied by Cementa Ltd., Sweden. Their support is greatly appreciated along with the technical help from the lab staff at LTU. Further, the AASC research, to a great extent, was financed by the Government of Iraq. 


\section{References}

[1] A. Palomo, M. W. Grutzeck, and M. T. Blanco, "Alkaliactivated fly ashes," Cement and Concrete Research, vol. 29, no. 8, pp. 1323-1329, 1999.

[2] J. L. Provis and J. S. J. van Deventer, Alkali Activated materials: State-of-the-Art Report, Springer, Berlin, Germany, RILEM TC 224-AAM, 2014.

[3] D. M. Roy, "Alkali-activated cements opportunities and challenges," Cement and Concrete Research, vol. 29, no. 2, pp. 249-254, 1999.

[4] J. L. Provis and S. A. Bernal, "Milestones in the analysis of alkali-activated binders," Journal of Sustainable Cement-Based Materials, vol. 4, no. 2, pp. 74-84, 2015.

[5] J. L. Provis, A. Palomo, and C. Shi, "Advances in understanding alkali-activated materials," Cement and Concrete Research, vol. 78, pp. 110-125, 2015.

[6] G. Turu'allo, "Early age strength development of GGBFS concrete cured under different temperatures," Doctoral thesis, University of Liverpool, p. 588, Liverpool, UK, 2013.

[7] M. Heikal, M. Nassar, G. El-Sayed, and S. Ibrahim, "Physicochemical, mechanical, microstructure and durability characteristics of alkali activated Egyptian slag," Construction and Building Materials, vol. 69, pp. 60-72, 2014.

[8] M. Nedeljkovic, K. Arbi, Y. Zuo, and G. Ye, "Microstructural and mineralogical analysis of alkali activated fly ash-slag pastes," in Proceedings of the 3rd International RILEM Conference on Microstructure Related Durability of Cementitious Composites, pp. 1-10, Nanjing, China, 2016.

[9] C. Cartwright, F. Rajabipour, and A. Radlińska, "Shrinkage characteristics of alkali-activated slag cements," Journal of Materials in Civil Engineering, vol. 27, no. 7, 2015.

[10] A. Gruskovnjak, B. Lothenbach, F. Winnefeld et al., "Hydration mechanisms of super sulphated slag cement," Cement and Concrete Research, vol. 38, no. 7, pp. 983-992, 2008.

[11] M. B. Haha, B. Lothenbach, G. Le Saout, and F. Winnefeld, "Influence of slag chemistry on the hydration of alkaliactivated blast-furnace slag-part II: effect of $\mathrm{Al}_{2} \mathrm{O}_{3}$," $\mathrm{Ce}$ ment and Concrete Research, vol. 42, no. 1, pp. 74-83, 2012.

[12] K. Gong and C. E. White, "Impact of chemical variability of ground granulated blast-furnace slag on the phase formation in alkali-activated slag pastes," Cement and Concrete Research, vol. 89, pp. 310-319, 2016.

[13] F. Puertas, M. Palacios, H. Manzano, J. S. Dolado, A. Rico, and J. Rodríguez, "A model for the C-A-S-H gel formed in alkaliactivated slag cements," Journal of the European Ceramic Society, vol. 31, no. 12, pp. 2043-2056, 2011.

[14] I. Garcia-Lodeiro, A. Palomo, A. Fernández-Jiménez, and D. E. Macphee, "Compatibility studies between N-A-S-H and $\mathrm{C}-\mathrm{A}-\mathrm{S}-\mathrm{H}$ gels. Study in the ternary diagram $\mathrm{Na}_{2} \mathrm{O}-\mathrm{CaO}-$ $\mathrm{Al}_{2} \mathrm{O}_{3}-\mathrm{SiO}_{2}-\mathrm{H}_{2} \mathrm{O}$," Cement and Concrete Research, vol. 41, no. 9, pp. 923-931, 2011.

[15] I. G. Lodeiro, D. Macphee, A. Palomo, and A. FernándezJiménez, "Effect of alkalis on fresh C-S-H gels. FTIR analysis," Cement and Concrete Research, vol. 39, no. 3, pp. 147-153, 2009.

[16] S. A. Bernal and J. L. Provis, "Durability of alkali-activated materials: progress and perspectives," Journal of the American Ceramic Society, vol. 97, no. 4, pp. 997-1008, 2014.

[17] A. Fernández-Jiménez, F. Puertas, I. Sobrados, and J. Sanz, "Structure of calcium silicate hydrates formed in alkalineactivated slag: influence of the type of alkaline activator," Journal of the American Ceramic Society, vol. 86, no. 8, pp. 1389-1394, 2003.
[18] T. Bakharev, J. G. Sanjayan, and Y.-B. Cheng, "Effect of admixtures on properties of alkali-activated slag concrete," Cement and Concrete Research, vol. 30, no. 9, pp. 1367-1374, 2000.

[19] V. Baroghel-Bouny, P. Mounanga, A. Khelidj, A. Loukili, and N. Rafaï, "Autogenous deformations of cement pastes," Cement and Concrete Research, vol. 36, no. 1, pp. 123-136, 2006.

[20] K. Kovler and S. Zhutovsky, "Overview and future trends of shrinkage research," Materials and Structures, vol. 39, no. 9, pp. 827-847, 2006.

[21] E. Tazawa, R. Sato, E. Sakai, and M. S., "Work of JCI committee on autogenous shrinkage," in Procedings of the Shrinkage 2000-Int. RILEM Workshop on Shrinkage of Concrete, pp. 21-40, Madrid, Spain, November 2000.

[22] E.-I. Tazawa, S. Miyazawa, and T. Kasai, "Chemical shrinkage and autogenous shrinkage of hydrating cement paste," Cement and Concrete Research, vol. 25, no. 2, pp. 288-292, 1995.

[23] B. Bissonnette, P. Pierre, and M. Pigeon, "Influence of key parameters on drying shrinkage of cementitious materials," Cement and Concrete Research, vol. 29, no. 10, pp. 1655-1662, 1999.

[24] F. Sayahi, Plastic Shrinkage Cracking in Concrete, ETH Zürich, Zürich, Switzerland, 2016.

[25] F. Collins and J. G. Sanjayan, "Effect of pore size distribution on drying shrinking of alkali-activated slag concrete," Cement and Concrete Research, vol. 30, no. 9, pp. 1401-1406, 2000.

[26] A. A. M. Neto, M. A. Cincotto, and W. Repette, "Drying and autogenous shrinkage of pastes and mortars with activated slag cement," Cement and Concrete Research, vol. 38, no. 4, pp. 565-574, 2008.

[27] N. K. Lee, J. G. Jang, and H. K. Lee, "Shrinkage characteristics of alkali-activated fly ash/slag paste and mortar at early ages," Cement and Concrete Composites, vol. 53, pp. 239-248, 2014, http://www.sciencedirect.com/science/ article/pii/S0958946514001255.

[28] C. Duran Atics, C. Bilim, Ö. Çelik, and O. Karahan, "Influence of activator on the strength and drying shrinkage of alkaliactivated slag mortar," Construction and Building Materials, vol. 23, no. 1, pp. 548-555, 2009.

[29] M. B. Haha, G. Le Saout, F. Winnefeld, and B. Lothenbach, "Influence of activator type on hydration kinetics, hydrate assemblage and microstructural development of alkali activated blast-furnace slags," Cement and Concrete Research, vol. 41, no. 3, pp. 301-310, 2011.

[30] F. Pacheco-Torgal, J. Castro-Gomes, and S. Jalali, "Alkaliactivated binders: a review. part 2. about materials and binders manufacture," Construction and Building Materials, vol. 22, no. 7, pp. 1315-1322, 2008.

[31] T. Bakharev, J. G. Sanjayan, and Y.-B. Cheng, "Effect of elevated temperature curing on properties of alkali-activated slag concrete," Cement and Concrete Research, vol. 29, no. 10, pp. 1619-1625, 1999.

[32] Y. Gu, Y. Fang, D. You, Y. Gong, and C. Zhu, "Properties and microstructure of alkali-activated slag cement cured at belowand about-normal temperature," Construction and Building Materials, vol. 79, pp. 1-8, 2015.

[33] R. J. Thomas, D. Lezama, and S. Peethamparan, "On drying shrinkage in alkali-activated concrete: improving dimensional stability by aging or heat-curing," Cement and Concrete Research, vol. 91, pp. 13-23, 2017.

[34] H. Ye, C. Cartwright, F. Rajabipour, and A. Radlińska, "Effect of drying rate on shrinkage of alkali-activated slag cements," in Proceedings of Tej 4th International Conference on the 
Durability of Concrete Structures, Lafayette, Indiana, USA, July 2014.

[35] J. J. Thomas, A. J. Allen, and H. M. Jennings, "Density and water content of nanoscale solid $\mathrm{C}-\mathrm{S}-\mathrm{H}$ formed in alkaliactivated slag (AAS) paste and implications for chemical shrinkage," Cement and Concrete Research, vol. 42, no. 2, pp. 377-383, 2012.

[36] M. Palacios and F. Puertas, "Effect of shrinkage-reducing admixtures on the properties of alkali-activated slag mortars and pastes," Cement and Concrete Research, vol. 37, no. 5, pp. 691-702, 2007.

[37] A. R. Sakulich and D. P. Bentz, "Mitigation of autogenous shrinkage in alkali activated slag mortars by internal curing," Materials and Structures, vol. 46, no. 8, pp. 1355-1367, 2013.

[38] M. H. Al-Majidi, A. Lampropoulos, A. Cundy, and S. Meikle, "Development of geopolymer mortar under ambient temperature for in situ applications," Construction and Building Materials, vol. 120, pp. 198-211, 2016.

[39] K. Orosz, Early age autogenous deformation and cracking of cementitious materials-implications on strengthening of concrete structures, Ph.D. thesis, Luleå University of Technology, Luleå, Sweden, 2017.

[40] K. Orosz, H. Hedlund, and A. Cwirzen, "Effects of variable curing temperatures on autogenous deformation of blended cement concretes," Construction and Building Materials, vol. 149, pp. 474-480, 2017, ISSN 0950-0618, E-ISSN 1879-0526.

[41] A. B. Klausen, Early Age Crack Assessment of Concrete Structures: Experimental Investigation of Decisive Parameters, 2016.

[42] Ø. Bjøntegaard, “Thermal dilation and autogenous deformation as driving forces to self-induced stresses in high performance concrete," Doctoral thesis, The Norwegian University of Science and Technology, Trondheim, Norway, 1999.

[43] E. J. Sellevold and $\varnothing$. Bjøntegaard, "Coefficient of thermal expansion of cement paste and concrete: mechanisms of moisture interaction," Materials and Structures, vol. 39, no. 9, pp. 809-815, 2006.

[44] Z. C. Grasley and D. A. Lange, "Thermal dilation and internal relative humidity of hardened cement paste," Materials and Structures, vol. 40, no. 3, pp. 311-317, 2007.

[45] D. Cusson and T. Hoogeveen, "Measuring early-age coefficient of thermal expansion in high-performance concrete," in Proceedings of the International RILEM Conference on Volume Changes of Hardening Concrete: Testing and Mitigation. RILEM Publication, Lyngby, Denmark, 2006.

[46] R. Loser, B. Münch, and P. Lura, "A volumetric technique for measuring the coefficient of thermal expansion of hardening cement paste and mortar," Cement and Concrete Research, vol. 40, no. 7, pp. 1138-1147, 2010.

[47] I. Chu, S. H. Kwon, M. N. Amin, and J.-K. Kim, "Estimation of temperature effects on autogenous shrinkage of concrete by a new prediction model," Construction and Building Materials, vol. 35, pp. 171-182, 2012.

[48] S. A. Bernal, "Advances in near-neutral salts activation of blast furnace slags,” RILEM Technical Letters, vol. 1, pp. 39-44, 2016.

[49] X. Ke, S. A. Bernal, and J. L. Provis, "Controlling the reaction kinetics of sodium carbonate-activated slag cements using calcined layered double hydroxides," Cement and Concrete Research, vol. 81, pp. 24-37, 2016.

[50] W. Chen and H. J. H. Brouwers, "The hydration of slag, part 1: reaction models for alkali-activated slag," Journal of Materials Science, vol. 42, no. 2, pp. 428-443, 2007.
[51] B. Lothenbach and F. Winnefeld, "Thermodynamic modelling of the hydration of Portland cement," Cement and Concrete Research, vol. 36, no. 2, pp. 209-226, 2006.

[52] K. Gu, F. Jin, A. Al-Tabbaa, B. Shi, and J. Liu, "Mechanical and hydration properties of ground granulated blastfurnace slag pastes activated with $\mathrm{MgO}-\mathrm{CaO}$ mixtures," Construction and Building Materials, vol. 69, pp. 101-108, 2014.

[53] R. J. Myers, S. A. Bernal, and J. L. Provis, "Phase diagrams for alkali-activated slag binders," Cement and Concrete Research, vol. 95, pp. 30-38, 2017.

[54] H. Ye and A. Radlińska, "Quantitative analysis of phase assemblage and chemical shrinkage of alkali-activated slag," Journal of Advanced Concrete Technology, vol. 14, no. 5, pp. 245-260, 2016.

[55] S.-D. Wang and K. L. Scrivener, " ${ }^{29} \mathrm{Si}$ and ${ }^{27} \mathrm{Al}$ NMR study of alkali-activated slag," Cement and Concrete Research, vol. 33, no. 5, pp. 769-774, 2003.

[56] C. Li, H. Sun, and L. Li, "A review: the comparison between alkali-activated slag $(\mathrm{Si}+\mathrm{Ca})$ and metakaolin $(\mathrm{Si}+\mathrm{Al})$ cements," Cement and Concrete Research, vol. 40, no. 9, pp. 1341-1349, 2010. 


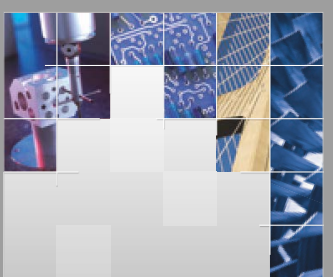

\section{Enfincering}
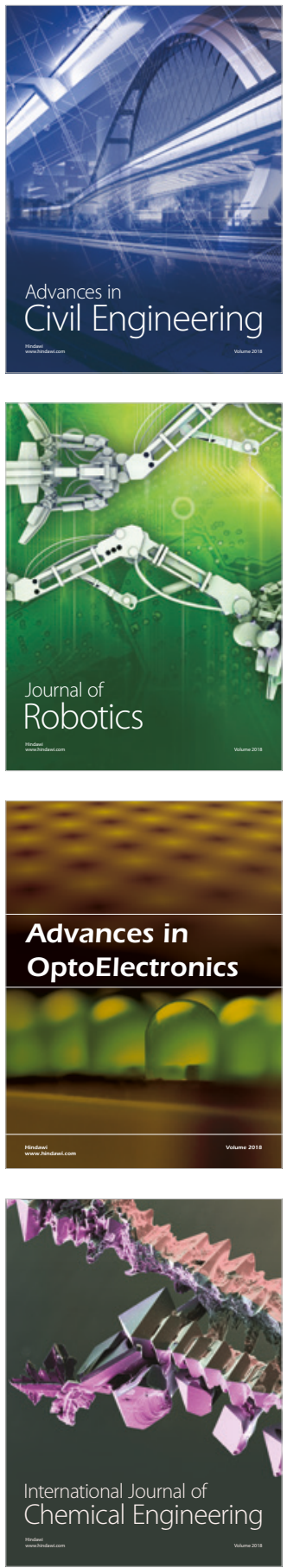

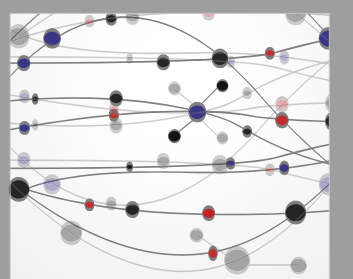

\section{Rotating \\ Machinery}

The Scientific World Journal

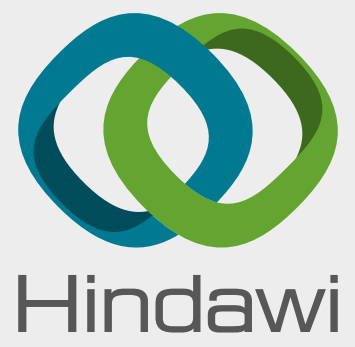

Submit your manuscripts at

www.hindawi.com
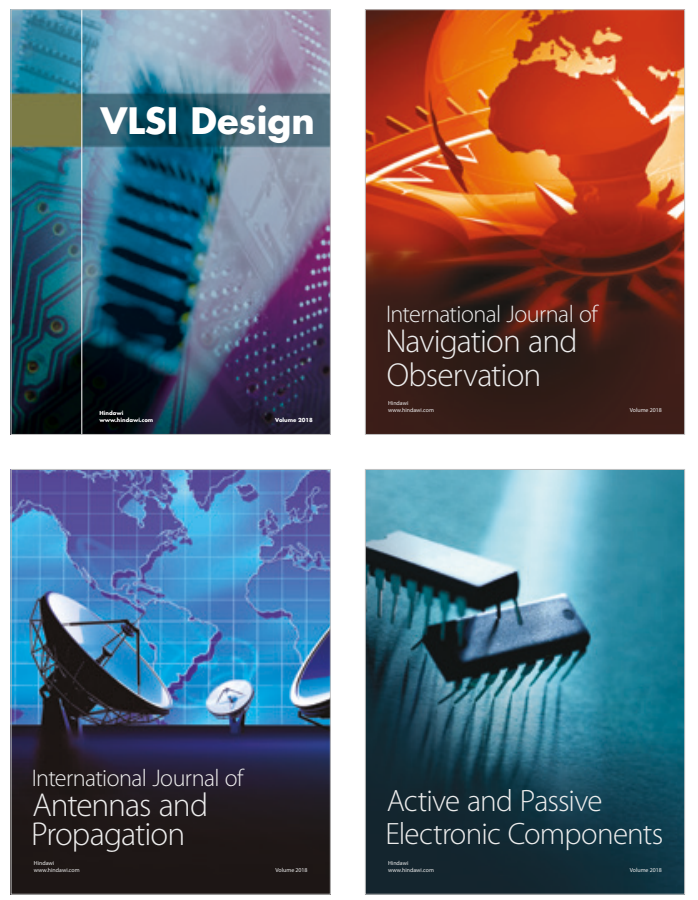
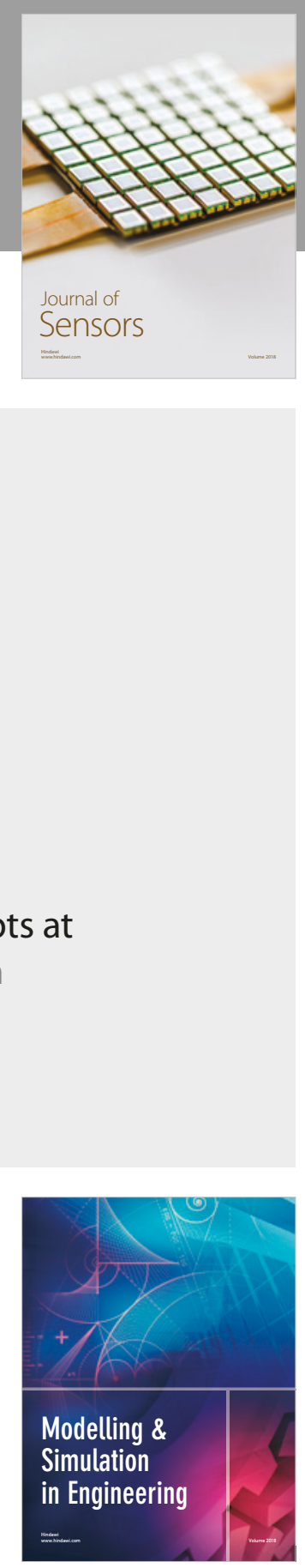

\section{Advances \\ Multimedia}
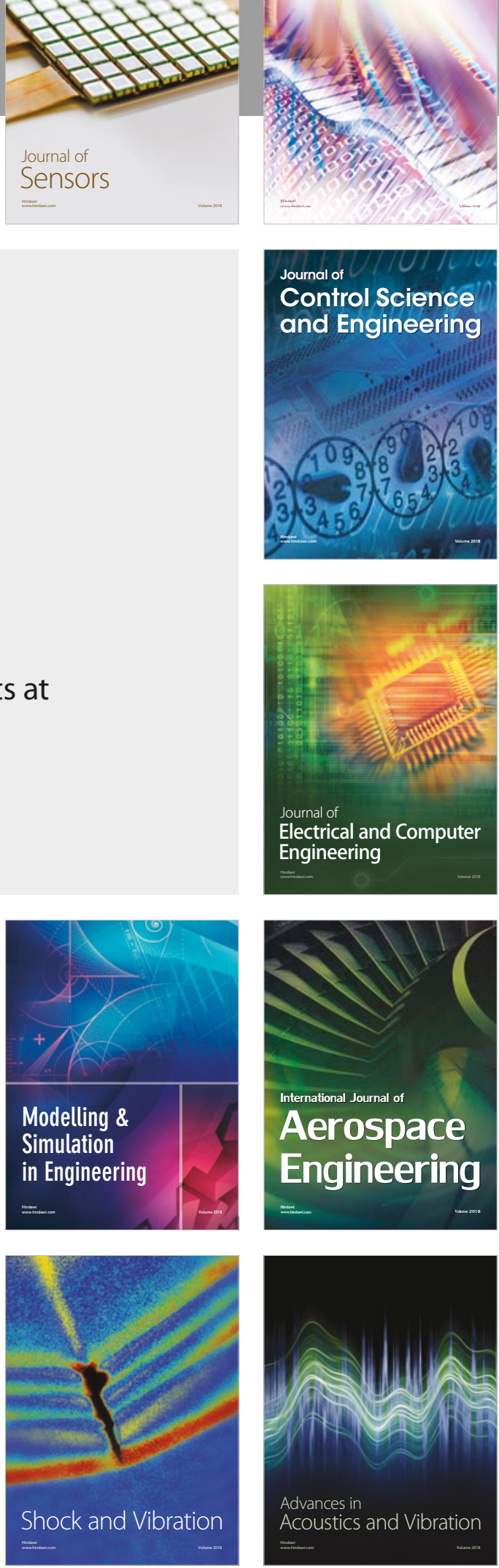